\title{
Analysis of Patented Homeopathic Products and Medicines in Brazil
}

\author{
Dyêggo Carvalho Amorim ', Marcela Napoleão de Oliveira', Ismael Nobre de Sena Silva', Leonardo Jorge Alves Bezerra', Luíza Maria \\ Oliveira Cavalcante ${ }^{1}$, Karine Jorge Alves Bezerra ${ }^{1}$, Stefanie Queiroz Ribeiro', Talita Mendes Bezerra Ximenes ${ }^{1}$, Robério Crister Rabelo Lima \\ Filho', Rui Pimenta Saldanha', Edilson Martins Rodrigues Neto ${ }^{2, *}$ \\ 'School of Medicine, Unichristus, Fortaleza Ceará, BRAZIL. \\ ${ }^{2}$ School of Pharmacy, Unicatólica, Quixadá Ceará, BRAZIL.
}

\begin{abstract}
Objectives: This study was to carry out a prospective study on the patents reports of homeopathic formulations in the brazilian intellectual property bank, the National Institute of Industrial Property (INPI). Methods: This is a prospective research of patents referring to homeopathy products and medicines carried in May 2020. Searches were made for patents deposited with homeopathic purpose with the terms "homeopathy" and "homeopathic" from the first document until the last one deposited in 2019. We have found thirty-eight deposits with the search terms cited above, after exclusion of duplicates we selected twenty four. Results: Among the 24 patent reports selected, 15 (62.5\%) were patents of invention. Among the classification of products, we highlight those of type A61K with 19 (79.1\%). Twenty-four deposits were selected with the search terms "homeopathy" and "homeopathic". 20 (83.3 \%) deposits with the term "homeopathic" and 4 (16.66\%) to the term "homeopathy". Among the reports stand out patents of homeopathic formulations 14 (58.3\%). There
\end{abstract}

were a greater number of deposits in the years 2009 and 2013, both with $4(16.6 \%)$ deposits. Conclusion: After analyzing patents on homeopathic products at the intellectual property bank in Brazil, it is concluded that most are related to new formulations. It can be seen that in Brazil the interest in relation to the protection of intellectual property in this topic is still small. Key words: Homeopathy, Homeopathic medicines, Pharmacy, Property Intellectual, Patents.

Correspondence

Dr. Edilson Martins Rodrigues Neto

School of Pharmacy, Unicatólica, Quixadá Ceará, BRAZIL.

Phone: +5521011464

Email: edilsonmrneto@gmail.com

DOI: 10.5530/jyp.2020.12.69

\section{INTRODUCTION}

In ancient Greece, Hippocrates, considered the creator of Medicine, argued that diseases could be treated both by the 'principle of contraries' (contraria contrariis curantur) and by the 'principle of similars' (similia similibus curantur). These concepts were followed by several exponents of the medical schools of the future, so emerged the homeopathy. ${ }^{1}$

A homeopathy was founded in 1796 by the german doctor Samuel Hahnemann and is currently a therapeutic model used worldwide, which has aroused or increased the interest of users, students and doctors. This specialty provides a safe, inexpensive practice that allows understanding and treating the binomial disease-disease according to a global and integrative approach, thus valuing different aspects of the individuality of the patient. Homeopathy is a therapeutic method that consists of prescribing to a sick patient, in a diluted form and in very small doses, a drug substance that, in high doses, is capable of producing in a healthy individual signs and symptoms similar to the disease that occurs. ${ }^{2}$

The homeopathy is considered a therapeutic model used for the treatment of human disease, in this context numerous adjectives it is assigned, as an alternative medicine, complementary, non-conventional adjuvant, integrative, etc. According to the World Health Organization (WHO), 'the terms 'complementary' and 'alternative' are used to refer to a group of health practices that are not part of a country's tradition, or are not integrated into its health system prevalent ".

Because it is considered an efficient and safe alternative, increasing clinical resolution, reducing the costs and iatrogenic effects of conventional pharmacological therapy, WHO in the last decades has encouraged the development of homeopathic projects to increase its availability to public health systems worldwide. In Brazil, the Ministry of Health recently approved the "National Policy on Integrative Practices and complements res in the Health System", encouraging and supports ing aid projects, teaching and research homeopathic in the various spheres of brazilian public health system, as well as other practices, for example herbal medicine and phytotherapy. ${ }^{2}$

It is known that the homeopathic model for treating diseases is based on four pillars: the principle of healing by similarity (therapeutic similarity); in experimenting with medications on healthy individuals (homeopathic pathogenic assays); in the prescription of individualized drugs and use of dynamited (ultra-diluted) drugs. ${ }^{1}$

In Brazil, homeopathy was recognized as a medical specialty by the Federal Council of Medicine in the 1980s, thus applying the principles that homeopathic medicine is a medical rationale, that is, a structured and integrated set of practices and knowledge, with its own understandings of a human morphology, physiology and medical doctrine. Thus, according to its principles, homeopathy cannot be reduced to a therapy or to an isolated diagnostic method, but a distinct specialty encompassing a medical and pharmaceutical system complex to a philosophical system. This definition prevents this specialty from following the principles of a rational medical model..$^{1-3}$

Currently, there is a growing investment made by research institutes and industries in researches that results in new products, new technologies and innovation. When researchers develop a new product, it can be 
patented. To do this, you must initially deposit in an intellectual property bank of some country and thus the inventor and his group will have exclusively the rights of the product for a period of time, which varies according to the level of product innovation and the legislation from the country. ${ }^{4,5,6}$

It is important to invest in new products, especially in industries, as this is essential for them to remain in the market. With the patent filing, the product is protected from commercialization by people other than the inventors. It also guarantees the security of profits from possible negotiations between the owner or its groups with industries and companies. $^{7-9}$

Due to the growing interest in products homeopathic and consumption growth and marketing, the objective was to carry out a prospective study on the amount of product patents homeopathic in intellectual property bank Brazilian National Institute of Industrial Property (INPI). In addition, assess the main materials, types, classification and production by patent filings over the years.

\section{MATERIALS AND METHODS}

This is a documentary patent search carried out during the month of May 2020. Searches were carried out on patents reports deposited with homeopathic medicines protected in the Brazilian intellectual property

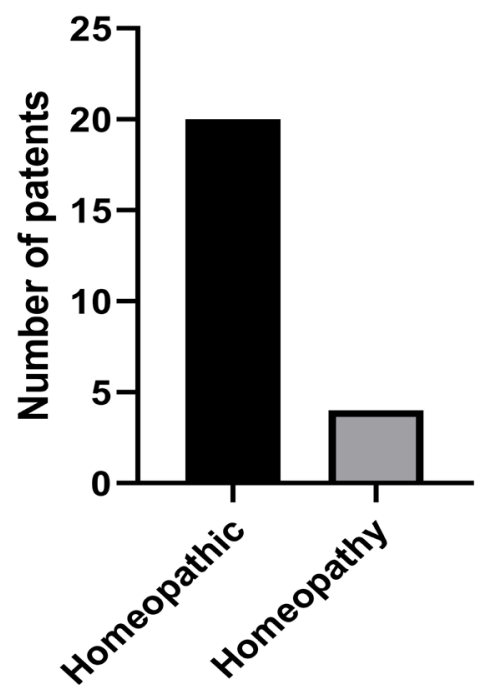

Graph 1: Number of patents reports published with the terms "homeopathy" or "homeopathic" found at the INPI, Brazil, 2019.

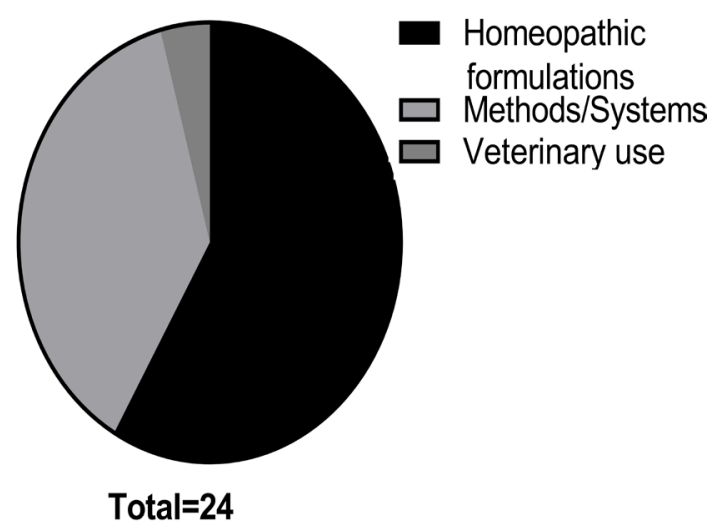

Graph 2: Types of products deposited with the terms "homeopathy" or "homeopathic" found at the INPI, Brazil, 2019. bank, the National Institute of Industrial Property (INPI) since the first product deposited until the last document found on this patent database. For this search, all patents that included the term "homeopathy" or "homeopathic" in the titles and abstracts were considered for analysis. We have found a total of thirty eight documents, then patent reports were selected after reading the title, summary or report without date restriction. After the exclusion of the duplicated reports, were selected a total of 24 reports of patents. The data obtained were organized into graphs in GraphPad Prism 6 program.

\section{RESULTS}

Twenty-four deposits were selected with the search terms "homeopathy" and "homeopathic" (Graph 1). Among them 20 (83.3 \%) deposits with the term "homeopathic" and $4(16.66 \%)$ to the term "homeopathy". Among these, a total of 15 (62.5\%) were classified as invention patent (IP) type and $9(37.5 \%)$ as the utility model (UM) type.

In graph 2 we can observe the products types of deposits on 2019. It is thus highlighting of new patents homeopathic formulations 14 (58.3\%). In addition, 9 patents were found for new methods and systems for obtaining homeopathic medicines (37.5\%) and 1 (4.2\%) for veterinary use (Graph 2).

On the graph 3 we can see the classifications according to the International Patent Classification. The most of the documents were related to the A61K classification of products, totaling 19 reports of patents (79.1\%) (Graph 3).

On the graph 4 we can found the relation of product reports deposited along the years. There were a greater number of deposits in the years 2009 and 2013, both with 4 (16.6\%) deposits. The year of 2007 had 3 (12.5\%) deposits, 2001 and 2011 had 2 (8.3\%) deposits. On the remaining years $(1982,1987,1994,2004,2008,2012,2014,2015$ and 2016) we can found a decrease of reports, scoring only 1 deposit (4.1\%) (Graph 4).

\section{DISCUSSION}

This research evaluated all the reports of patents about homeopathy products in Brazil. In the complex debate about the need for alternative treatments and medicines, the lack of knowledge of many of the homeopathic principles and their functioning ends up harming the debate when the policies for implementing this specialty in the public service, for example. There is a reluctance of traditional medicine to accept the four fundamental principles of homeopathy, such as the law of similarity, experimentation in healthy people, the dynamization of the medicine and the individualized medicine. The comprehensiveness of a medical treatment must be more than a global approach to patient

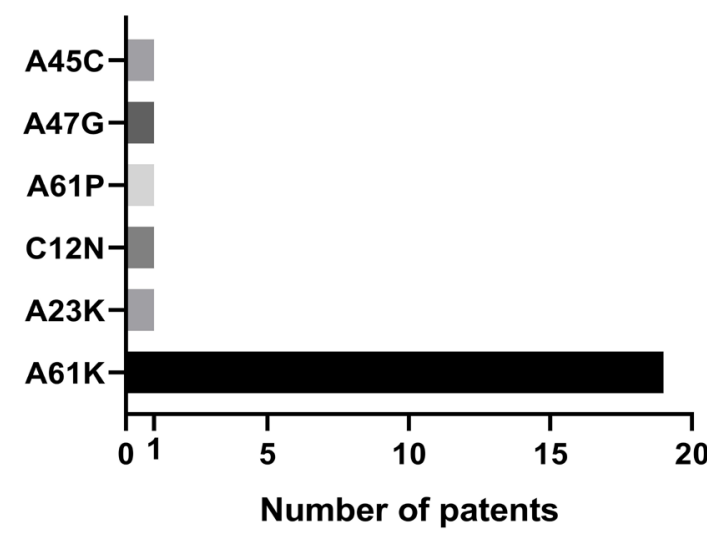

Graph 3: Classification of published patents with the terms "homeopathy" or "homeopathic" at the INPI, Brazil, 2019. 


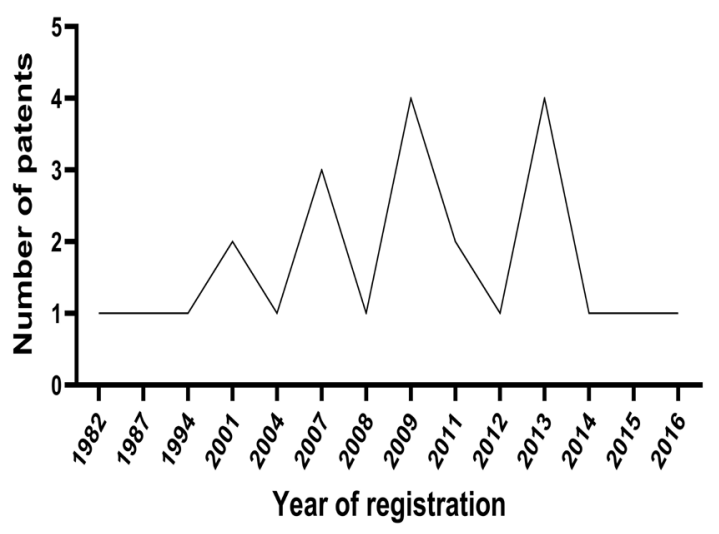

Graph 4: Relationship between the number of products and years of the published patents with the terms "homeopathy" or "homeopathic" at the INPI, Brazil, 2019.

health, it consists in treating the totality in each sphere of human health. This approach brings several benefits to the patient regardless of the therapeutic model to be followed, in addition to being one of the principles of the brazilian public health system. In this regard, homeopathy is a specialty that perfectly meets this principle, since the treatment is guided by integrality and individuality, since the prescription of the medication is made based on the characteristic symptoms. ${ }^{1-3}$

In this study, the patent reports related to homeopacthic products and medicines deposited in Brazil have been revised in this study in order to evaluate the current status of brazilian products that which have been developed and intellectually protected, taking into account the reality of some countries in South America. Founding only twenty four reports of patents on the National Institute of Industrial Property we can see and concluse that this may be a reflection of the fact that brazilian scientific and industrial production in homeopathic products and medicines is small, seeing the world context.

Another importante point, especially in multinationals companies, to make the deposit in countries other than those of origin of the product's origin, in order to increase the product's protection and disclosure of the product, normally which is normallythis is done through the Patent Cooperation Treaty - PCT. In the present study we did not find any document protected through PCT method, this is another indicator of the small investment on homeopathic products and medicines to treat diseases. ${ }^{4-7}$

Despite being used for more than two centuries worldwide, homeopathy remains marginalized in the face of modern scientific rationality, as it is based on unorthodox paradigms, thus challenging the dominant system. ${ }^{2}$ The increase in interest and the search for "Non-Conventional Health Practices" is a phenomenon that grows worldwide, not only in Brazil, with emphasis on herbal medicine, homeopathy and acupuncture. Interest and demand is increasing the addition of homeopathy to undergraduate curricula and specialization courses. ${ }^{1}$

In Brazil, since 1980 Homeopathy has been recognized as a medical specialty, but its presence in universities is still rare. The reduced number of deposits is due to the still unknown and consequent lack of research on Homeopathy. However, this trend is expected to grow, given the expansion of homeopathic care in the public network after the publication of Ordinance 971II, with the Ministry of Health's policy for non-conventional medicines. Possibly, when Homeopathy is a major reality in undergraduate and graduate courses, a greater number of products resulting from research will become a reality. ${ }^{10}$

In order to facilitate searches, patents have an international classification system created in 1971 that distributes them by letter and number codes, which is known as IPC, which divides products into technological areas from classes A to $\mathrm{H}$, where each class has its own subdivision. This classification emerged as a search tool and easy to access, so as to expand the promotion of the product. ${ }^{8,11}$

In the search carried out, the deposits were limited to 6 types. The A61K code was the one with the most deposits and is related to products for medical, dental and hygienic purposes. In this study, a greater amount of type A products was perceived, which was something expected, since it is the code that encompasses products such as medicines.

The great debate regarding intellectual property is still small in most countries in the world, including Brazil, however it has gained notoriety especially in research institutions. Law 9,279, of May 14, 1996, which deals with patent legislation, was a milestone on the subject in Brazil. Another milestone was Law No. 10,973, of December 2, 2004, which deals with measures to encourage innovation and scientific and technological research, thus authorizing the Union, states and municipalities and development agencies to encourage interaction between companies and entities focused on scientific and technological research. ${ }^{11-13}$

The daily changes that occur in the world economy affect all countries of the globe, including the least developed ones, since globalization stimulates scientific and technological development in companies and research institutions, where the development of new products is a strong indicator of this innovation.

\section{CONCLUSION}

After analyzing the documents of patents on homeopathic products nd medicines at the intellectual property bank in Brazil, it is concluded that most are related to the area of new formulations of medicines. It can be seen that in Brazil the interest in relation to the protection of intellectual property in this topic is still small despite being an area that has been gaining increasing notoriety in research and drug development.

\section{ACKNOWLEDGEMENT}

The authors acknowledge the School of Medicine,Unichristus, Brazil.

\section{CONFLICT OF INTEREST}

The authors declare no conflict of interest.

\section{ABBREVIATIONS}

INPI: National Institute of Industrial Property; IPC: International Patent Classification; PCT: Patent Cooperation Treaty; WHO: World Health Organization.

\section{REFERENCES}

1. Teixeira MZ. Fundamentação científica do princípio de cura homeopático na farmacologia moderna. Rev Homeopat. 2017;80(1):27-51.

2. Teixeira MZ. Homeopatia: Ciência, filosofia e arte de curar. Rev Med. 2006;85(2):30-43

3. Teixeira MZ. Homeopatia: Desinformação e preconceito no ensino médico. Rev Bras Educ Med. 2007;31(1):15-20.

4. Ferreira AA, Guimarães ER, Contador JC. Patente como instrumento competitivo e como fonte de informação tecnológica. Gest Prod. 2009;16(2):209-21.

5. INPI. Instituto Nacional de Propriedade Industrial. 20116. Available in: <http:// www.inpi.gov.br>

6. Valadas LAR, DeOliveira-Filho RD, DeOliveira MBL, et al. Products of Dental Use Containing Copaiba Oil-resin: Technological Prospecting Based on Patents. Recent Pat Biotechnol. 2020;14(1):33-40.

7. JrAmadei JRP, Torkomian ALV. As patentes nas universidades: análise dos depósitos das universidades públicas paulistas (1995-2006). Cienc Inform. 2009;38(2):9-18

8. JrFurtado JH, Rocha VLA, Mendonça KS, et al. Propolis and its Dental Applications: A Technological Prospection. Recent Pat Biotechnol. 2018;12(4):288-96. 
9. Mueller SPM, Perucchi V. Universidades e a produção de patentes: Tópicos de interesse para o estudioso da informação tecnológica. Perspect Cienc Inform. 2014;19(2):15-36.

10. Salles SAC. A presença da homeopatia nas faculdades de medicina brasileiras: Resultados de uma investigação exploratória. Rev Bras Educ Med. 2008;32(3):283-90.

11. Machado BAS, Cruz LS, Nunes SB, Umsza MA, Guez, Padilha FF. Estudo prospectivo da própolis e tecnologias correlatas sob o enfoque em documentos de patentes depositados no brasil. Rev Geintec. 2012;2(3):221-35.

12. Dagnino RD, Silva RB. As patentes das universidades públicas. Econ and Tec. 2009;18(5):169-72

13. Valadas LAR, Queiroz LR, Bandeira MAM, et al. Analyses of deposited and
Granted Patents at Federal University of Ceara in Brazil. J Young Pharm. 2017;9(3):307-10.

14. Graph 1: Number of patents reports published with the terms "homeopathy" or "homeopathic" found at the INPI, Brazil, 2019.

15. Graph 2: Types of products deposited with the terms "homeopathy" or "homeopathic" found at the INPI, Brazil, 2019

16. Graph 3: Classification of published patents with the terms "homeopathy" or "homeopathic" at the INPI, Brazil, 2019.

17. Graph 4: Relationship between the number of products and years of the published patents with the terms "homeopathy" or "homeopathic" at the INPI, Brazil, 2019.

Article History: Submission Date : 30-05-2020; Revised Date : 30-06-2020; Acceptance Date : 16-07-2020

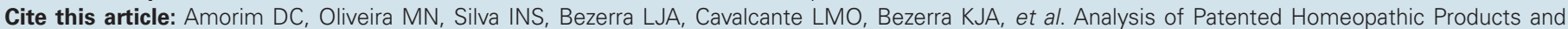
Medicines in Brazil. J Young Pharm. 2020;12(3):246-9. 